Technology and Gender 


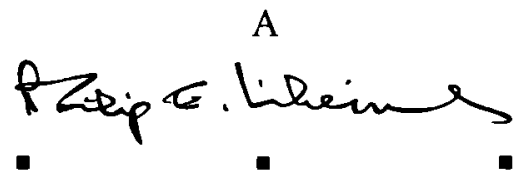

B $\mathrm{O} \quad \mathrm{O} \quad \mathrm{K}$

The Philip E. Lilienthal imprint honors special books in commemoration of a man whose work at the University of California Press from 1954 to 1979 was marked by dedication to young authors, and to high standards in the field of Asian Studies. Friends, family, authors, and foundations have together endowed the Lilienthal Fund, which enables the Press to publish under this imprint selected books in a way that reflects the taste and judgment of a great and beloved editor. 


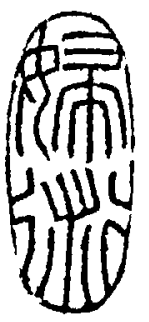

\section{Technology and Gender}

Fabrics of Power in

Late Imperial China

FRANCESCA BRAY

University of California Press

BERKELEY LOS ANGELES LONDON 
University of California Press

Berkeley and Los Angeles, California

University of California Press, Ltd.

London, England

(C) 1997 by

The Regents of the University of California

Library of Congress Cataloging-in-Publication Data

Bray, Francesca.

Technology and gender : fabrics of power in late imperial China /

Francesca Bray.

p. $\mathrm{cm}$.

"A Philip E. Lilienthal book."

Includes bibliographical references and index.

ISBN 0-520-20685-1 (alk. paper). — ISBN 0-520-20861-7

(pbk. : alk. paper)

1. Sex roles-China-History. 2. Women-China-Social condi-

tions. 3. Technology-Social aspects-China-History. 4. China-

Social conditions-960-1644. 5. China-Social conditions-1644-1912.

I. Title.

$\mathrm{HQ}_{76} 68 . \mathrm{B}_{72} 1997$

305.3'0951-dc20

$96-28828$

CIP

Printed in the United States of America

987654321

The paper used in this publication meets the minimum requirements of American National Standard for Information Sciences-Permanence of Paper for Printed Library Materials, ANSI Z39.48-1984.

The following chapters are revised versions of materials published elsewhere: chapter 5: "Le travail féminin dans la Chine impériale: sur l'élaboration de nouveaux motifs dans le tissu social," Annales, Histoire, Sciences Sociales 49, 4 (July-Aug. 1994): 783-816; chapter 6:

"Textile production and gender roles in China, 1000-1700," Chinese Science 12 (1995): 113-35; and chapter 7 : "A deathly disorder: understanding women's health in late imperial China," in Knowledge and the scholarly medical traditions, ed. Donald Bates (Cambridge: Cambridge University Press, 1995). These revised versions are reprinted here by permission.

Seal used as text ornament by Wu Jinyang. 
For Joseph 


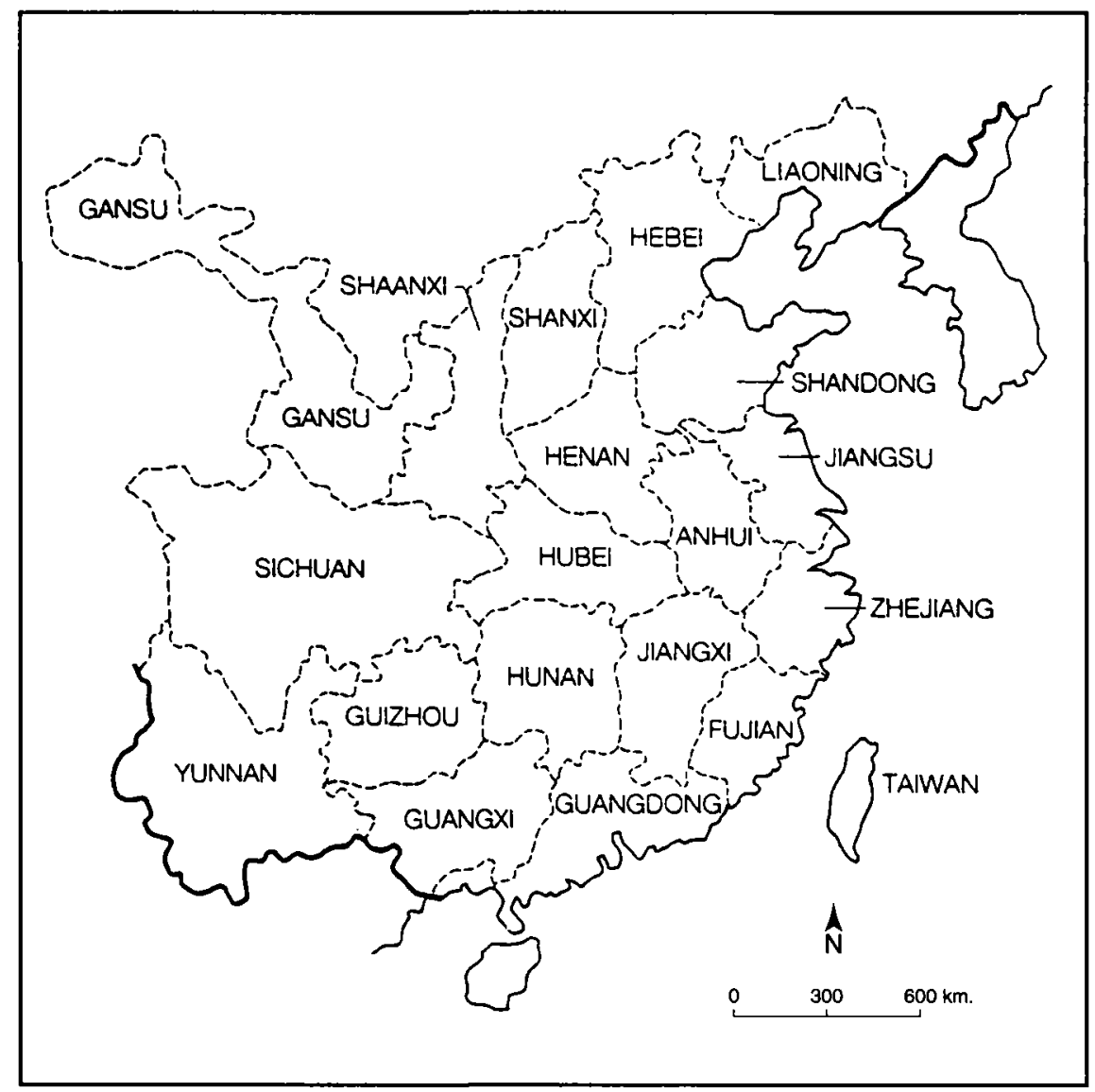

Map 1. Central provinces of modern China 


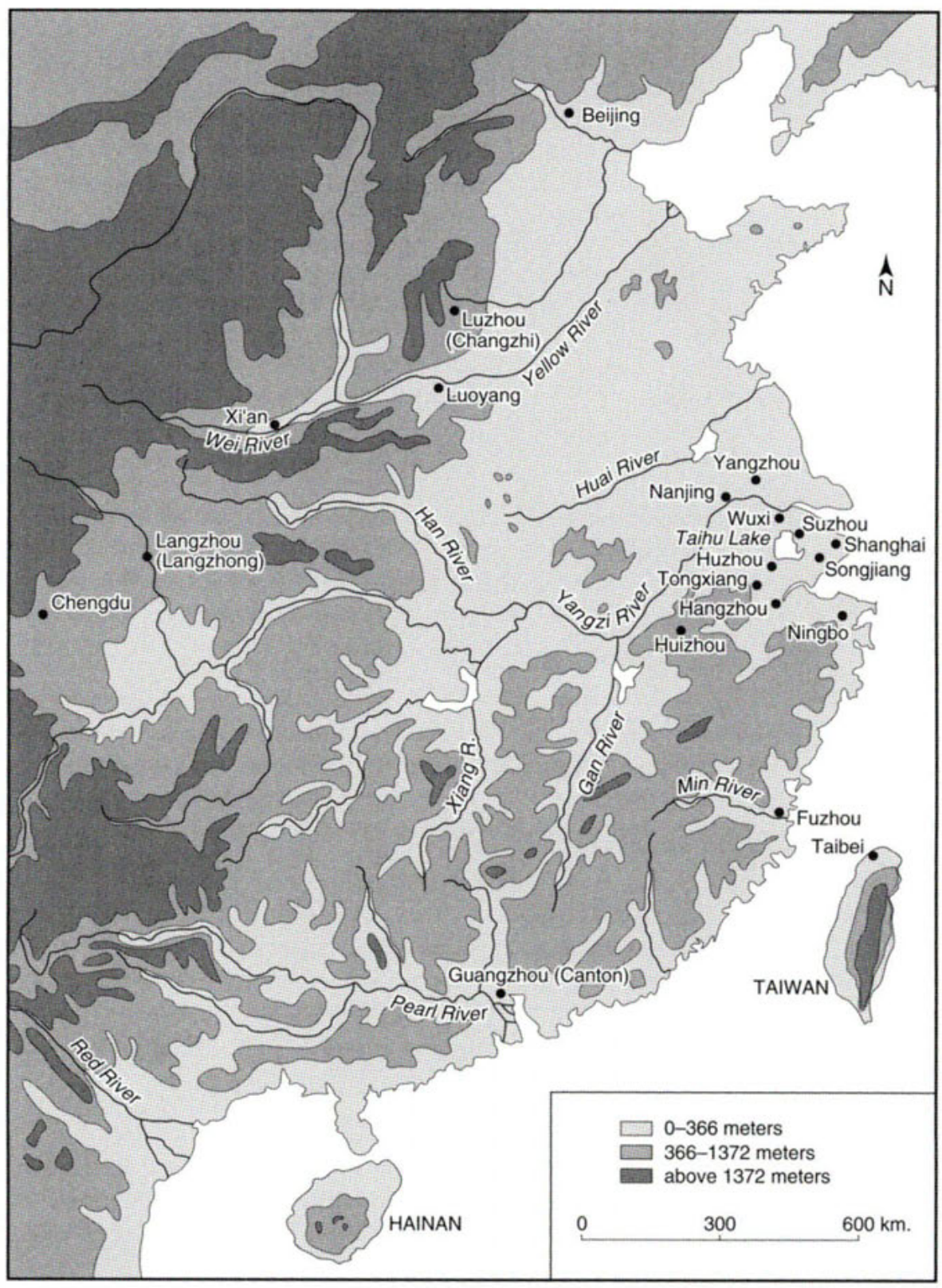

Map 2. Relief map of China 
